\title{
INVESTIGATION ON POSSIBILITIES FOR BIOGAS PRODUCTION FROM ORGANIC WASTE ON THE CROATIAN ISLAND OF KRK
}

\author{
Viktor Dragičević, Marin Miletić, Branimir Pavković
}

Original research paper The subject of this paper is the analysis of the possibilities of using biodegradable municipal and agricultural waste in a biogas energy production facility on the island of Krk. The main characteristic of this type of waste is the variable composition. The total amount of municipal waste on the largest Croatian island of Krk is relatively small in comparison to cities. Particularly significant is the high variability of feedstock volumes depending on the period in the year. As a result, the biogas production is unstable and varies on a monthly basis. To overcome that situation a scenario with two cogeneration units was compared to a scenario when only one unit is used. The approach of two units, that operate based on the available biogas inflow, has shown to be more efficient than using a single unit. Net GHG emissions are negative.

Keywords: organic waste; biogas; potential; cogeneration; GHG reduction

Analiza mogućnosti korištenja bioplina dobivenog fermentacijom biogenog otpada na hrvatskom otoku Krku

Izvorni znanstveni članak Predmet ovog rada je analiza mogućnosti korištenja biogenog dijela komunalnog i poljoprivrednog otpada u bioplinskom energetskom postrojenju na otoku Krku. Karakteristike ove vrste otpada su različiti sastav i velike sezonalne varijacije u količinama otpada. Ukupna količina komunalnog otpada na najvećem hrvatskom otoku Krku je relativno mala u usporedbi s gradskim središtima, iako postoje značajne oscilacije u količini otpada tijekom godine uslijed turističke aktivnosti tijekom ljeta. Na temelju dostupnih količina organskog otpada tijekom godine analiziran je energetski potencijal dobivenog bioplina s obzirom na dostupna tehnička rješenja za energetsko iskorištavanje istog. Bioplinsko postrojenje je predloženo za anaerobnu fermentaciju otpada i obradu bioplina. Simulacija efekata primjene bioplinskog i kogeneracijskog postrojenja za razdoblje od jedne godine je provedena kako bi se optimiziralo za maksimalnu energetsku efikasnost i proizvodnju električne i toplinske energije. Uspoređeni su scenariji sa korištenjem jedne ili dvije kogeneracijske jedinice. Rezultati pokazuju da je u slučaju veoma varijabilne proizvodnje bioplina tijekom godine energetski efikasnije korištenje dvije kogeneracijske jedinice. Emisije stakleničkih plinova su negativne.

Ključne riječi: biogeni otpad; bioplin; potencijal; kogeneracija; emisije stakleničkih plinova

\section{Introduction}

Biogas is a renewable and sustainable energy carrier generated via anaerobic digestion (AD) of biomass. It can be derived from various biomass resources i.e. sewage sludge, organic wastes, livestock manure and energy crops. Depending on its origin, biogas comprises methane $(40 \div 75 \%)$, carbon dioxide $(20 \div 45 \%)$ and some other compounds, usually in trace quantities. The use of material and energy potentials of biodegradable waste, in the framework of technical, ecological and economic possibilities, particularly contributes in reducing the environmental impacts and helps to meet the targets of GHG emission reduction, share of renewable energy in national energy objectives and material recovery from waste materials.

$\mathrm{AD}$ converts waste materials to useful feedstock creating a closed nutrient cycle offering competitive advantages when compared with other treatment options of the organic fractions of municipal solid waste (MSW). In comparison to waste incineration, with $\mathrm{AD}$ waste recovery valuable nutrients could be recovered for agriculture production displacing artificial fertilizers while energy content is effectively used in comparison to waste recovery with composting process alone. A variety of organic feedstock can be used for biogas production as long as they contain carbohydrates, proteins, fats and hemicelluloses as their main components [1]. The optimal mix of biogas feedstock depends on the choice of fermentation systems with respect to techno-economic criteria and the availability of biogas feedstock. Nonetheless, wet fermentation systems dominate in general based mostly on animal slurry with addition of co-substrates to increase the content of organic material for achieving a higher gas yield [2]. Exemplary biogas yield of different feedstock $[3,4,5]$ is outlined in Fig. 1 .

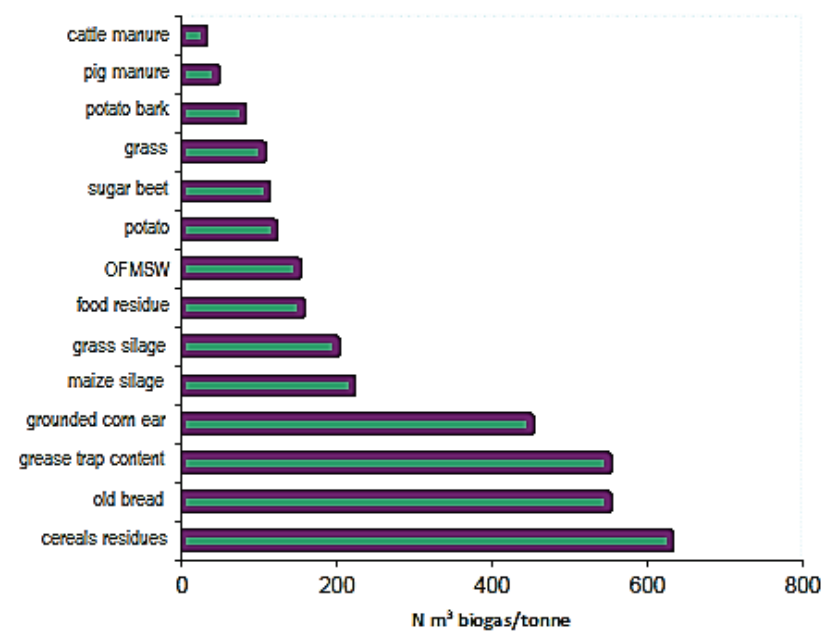

Figure 1 Biogas yield of different feedstock

The efficiency of an anaerobic digestion process primarily depends on the composition and nature of the feedstock [6]. Appropriate raw material for production of biogas must contain organic material that is suitable for anaerobic digestion. Such raw materials could include agricultural biomass residues, livestock residues, food waste, municipal solid waste, animal waste and sewage sludge. Unlike most substrates, OFMSW is a very complex type whose composition is highly unpredictable. 
In Croatia, conventional landfilling is still a commonly used method for the disposal of municipal solid waste (MSW). During waste degradation, a conservative percentage $(50 \%)$ of the total carbon in MSW is released as landfill gas and leachate [7]; $90 \%$ of the degradable carbon in these pollutants is usually converted into $\mathrm{CO}_{2}$ and $\mathrm{CH}_{4}$ [8]. $\mathrm{CH}_{4}$ produced at solid waste landfill sites contributes approximately $12 \div 18 \%$ of annual global anthropogenic methane emissions [9]. The GHG emission reductions with biogas systems normally lead to environmental benefits that can be considerable. Several studies relate the GHG savings when biogas produced from waste is used for energy production, and the side product digestate is recovered $[10,11,12]$.

The transition from waste landfilling to material and energy recovery is of utmost importance to reduce environmental impact and carbon footprint in order to slow climate change processes.

In Croatia the framework for the biodegradable waste management is arranged by the Waste Management Strategy of the Republic of Croatia (Official Gazette - OG 130/05) and Waste Management Plan of the Republic of Croatia for the period $2007 \div 2015$ (OG 85/07) and regulated by the Act on Sustainable Waste Management (OG 94/13). The legal framework for production and utilization of biogas is still in the phase of adaptation and upgrade with good practice.

According to the EU Landfill Directive, EU member states have to reduce the amount of biodegradable municipal waste (BMW) landfilled by a certain percentage by 2006, 2009 and 2016, related to the amount of BMW generated in 1995. In the accession negotiations with the EU it was agreed to use 1997 as the base year for Croatia. The $75 \%$ reduction target has to be fulfilled in 2013 and the $50 \%$ target in 2016. Obligatory separate collection of the biodegradable fraction of municipal waste has started recently but the recycling rate is still low. The main challenge is to increase separate collection from municipal waste and to develop the infrastructure for recycling and/or energy recovery of biowaste.

Croatia should make an exceptional effort in order to fulfil the $50 \%$ target of the Waste Framework Directive by 2020 as well as the diversion targets of the EU Landfill Directive.

In this paper we investigate the feasibility to use $\mathrm{AD}$ system on Croatian island of Krk to recover the biowaste produced locally and efficiently use the obtained biogas and the digestate as side product. The paper presents and discusses results obtained in a study [13] with emphasis on gas production system. The goal is the introduction of an integrated and sustainable management system of biogenic waste on the island to evaluate the effects of synergism and integrated use of biogas technology.

The specific objectives of the study, which will be described in detail in the individual sections, are as follows:

- to analyse the available substrate for biogas production on the island, with the determination of the amount and potential of biogas production;

- to assess the technical aspects for the realization of a cogeneration plant;

- $\quad$ to optimize the cogeneration plant in order to achieve maximum energy efficiency

- to calculate if the carbon footprint and the energy efficiency of the biowaste $\mathrm{AD}$ recovery system on the islands' environment would be acceptable and justified.

\section{Materials and methods}

To evaluate the availability of feedstock for biogas production on the island of Krk data were collected from the municipal company Ponikve regarding the monthly collected amount of organic fraction of municipal solid waste (OFMSW). Received information regarded two types of waste: kitchen and canteen waste $(200108)$ and biodegradable garden and park waste $\left(\begin{array}{lll}20 & 02 & 01\end{array}\right)$ in the period from the years 2009 to 2011 .

Table 1 Basic characteristics of substrate and the potential for biogas production on average yearly base

\begin{tabular}{|c|c|c|l|c|c|}
\hline \multicolumn{2}{|c|}{ Substrate } & \multicolumn{2}{c|}{ Methane-biogas } \\
\hline Amount, $\mathrm{t} /$ annum & $\mathrm{DM}^{*}, \%$ & $\mathrm{CH}_{4}, \%$ & \multicolumn{2}{c|}{ Oolume, $\mathrm{m}^{3}$} & Energy, $\mathrm{kW} \cdot \mathrm{h}$ \\
\hline 2332 & 30 & 62 & Kitchen and canteen waste (20 01 08) & 159068 & 1590683 \\
\hline 145 & 35 & 60 & Biodegradable garden and park waste $(200201)$ & 7838 & 78376 \\
\hline 85 & 15 & 68 & Pomace & 15551 & 155509 \\
\hline 9 & 12 & 60 & Whey & 470 & 4698 \\
\hline 400 & 20 & 65 & Poultry - liquid manure & 24960 & 249600 \\
\hline 104 & 19 & 62 & Olive cake & 226629 & 187424 \\
\hline 3075 & & & & TOTAL & 266289 \\
\hline
\end{tabular}

*DM - Dry Matter

For the purpose of additional analysis and determination of available feedstock for biogas production on the island, a questionnaire was submitted to public authorities and private companies active on the island to evaluate the availability of waste currently not collected by the company Ponikve. Suitable waste streams were determined. Based on these data, the usable quantities of respective waste fractions for anaerobic digestion, as well as the technical potentials for the energy production via biogas were calculated. The technical potential means the part of the present feedstock (theoretical potential) that can be used for biogas production by current technical possibilities including structural and ecological restrictions (e.g., established utilization paths). Energy and material balance was determined for anaerobic digestion of the above feedstock and biogas production. The biogas technology was assumed to be wet mesophilic digestion. Biogas yields and methane content obtained using selected feedstock were experimentally determined [13]. The composition of 
the biodegradable raw material for biogas production and the respective biogas yields are presented in Tab. 1.

To determine the potential for producing electric and heat energy in the cogeneration units a simulation has been performed with 2 different scenarios in order to calculate the produced energy for the varying rates of biogas production. Electric and heat production efficiency of cogeneration units is dependent on the heat load of the unit. Scenario 1 assumes the use of one cogeneration unit with maximum electric power output $199 \mathrm{~kW}$. Scenario 2 assumes the use of two cogeneration units, one with electric power output $140 \mathrm{~kW}$ and the other one with electric power output $50 \mathrm{~kW}$.

Cogeneration units with gas engines have optimal power efficiency in the span between $90 \div 100 \%$ of the nominal load. Lower loads can result in lower energy conversion efficiency, both electrical and thermal energy efficiency.

In the first case scenario (Case 1) a single cogeneration unit of $536 \mathrm{~kW}$ heat input and $199 \mathrm{~kW}$ electric power output is installed and it is operated at different loads depending on the biogas availability. This unit's load is capable of operating at maximum capacity in the month of September without interruptions. For the other months it operates at lower loads and with interruptions as the available biogas amounts are not sufficient.

The chosen cogeneration unit has an electrical efficiency curve that is declared by the manufacturer for three loads, $50 \%, 75 \%$ and $100 \%$. With this data a linear regression has been performed to determine the equation that relates heat load and electric efficiency (Fig. 2).

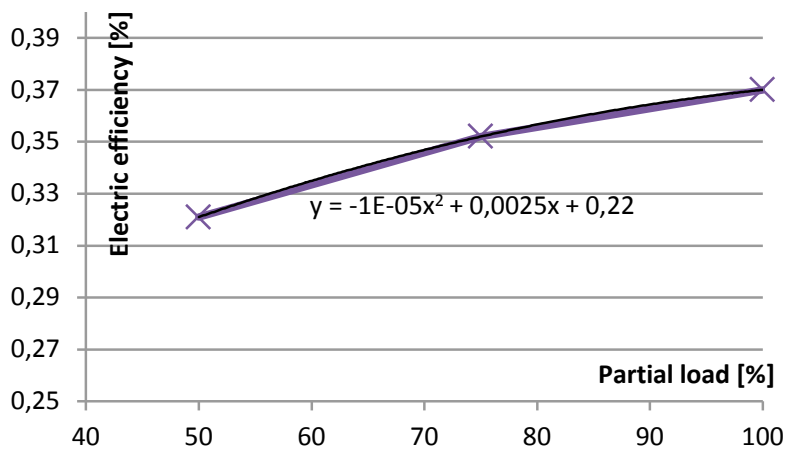

Figure 2 Electric efficiency curve - single cogeneration unit (199 kWel) - Case 1

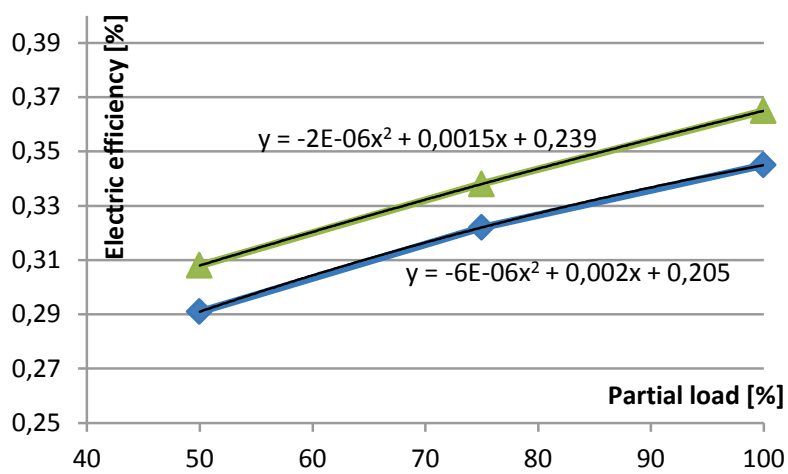

Figure 3 Electric efficiency curve - two cogeneration units (50 kWel and $140 \mathrm{kWel})-$ Case 2
The second case scenario (Case 2) assuming the use of two cogeneration units $(140 \mathrm{~kW}$ electric power and 50 $\mathrm{kW}$ electric power) has electrical efficiency curves declared for three loads, $50 \%, 75 \%$ and $100 \%$. Linear regression is used to determine the equation that relates heat load and electrical efficiency (Fig. 3).

For these two cases it is possible to simulate the operation of the biogas plant and calculate the expected electric energy production levels on monthly average bases.

In order to quantify overall GHG emissions from anaerobic digestion, a calculation is made for quantification of both GHG emissions and GHG avoidance.

The GHG accounting is done per ton of organic waste received at the $\mathrm{AD}$ facility and according to $14,15,16$ and 17.

We define the global warming factor (GWF) as: $\mathrm{GWF}=$ emission factor $(\mathrm{EF}) \times$ global warming potential (GWP)

Thus the GWFs are obtained by multiplication of the emission factor for each emission by the GWP for that emission according to the IPCC and is used to characterize, in $\mathrm{CO}_{2 \mathrm{eq}}$, the potential contribution to global warming by each sub-process of anaerobic digestion and digestate use per characteristic unit, for example, $\mathrm{kg} \mathrm{CH}_{4}$ lost by fugitive emission/ton waste. When added together the aggregated global warming factor represents the total potential contribution to global warming by anaerobic digestion and digestate use per ton of organic waste [16].

Emissions of $\mathrm{CO}_{2 \mathrm{eq}}$ are taken into account as emissions from operational activities such as consumption of fossil fuels associated with the fuel consumption for handling the feedstock; the consumption of electricity associated with the operation of the anaerobic digester; $\mathrm{CH}_{4}$ emissions from the digester (emissions during maintenance of the digester, physical leaks through the roof and side walls, and release through safety valves due to excess pressure in the digester) and $\mathrm{CH}_{4}$ and $\mathrm{N}_{2} \mathrm{O}$ emissions from composting of digestate. Emission sources associated with $\mathrm{N}_{2} \mathrm{O}$ emissions from physical leakages from the digester, transportation of feed material and digestate or any other on-site transportation, piped distribution of the biogas, aerobic treatment of liquid digestate and land application of the composted digestate are neglected because these are considered minor emission sources. $\mathrm{CH}_{4}$ emissions from flaring of biogas are not taken into account, as this would happen only in exceptional and therefore not accountable circumstances. $\mathrm{CH}_{4}$ and $\mathrm{N}_{2} \mathrm{O}$ emissions from biogas combustion in CHP unit are considered negligible. The GHG life cycle of digestate composting was not considered.

The GHG emission balance was calculated using the GHG emission factors presented in Tab. 2.

Emissions of $\mathrm{CO}_{2 \mathrm{eq}}$ for fuel consumption for transport and handling the waste at anaerobic digestion facilities are calculated as follows:

EM transport - Emissions from transport $\left(\mathrm{kg} \mathrm{CO}_{2 \text {-eq }} /\right.$ tone of organic waste) $=\mathrm{FC} \times \mathrm{EF}$ diesel fuel

FC - Fuel consumption (1 fuel/tone of organic waste) 
Considering that organic waste is transported in a 25 tones truck with an average consumption of 351 diesel fuel $/ 100 \mathrm{~km}$ we estimate 1,41 fuel consumption/ton organic waste. EF for combustion of diesel oil is $2,7 \mathrm{~kg}$ $\mathrm{CO}_{2 \mathrm{eq}} / 1$ (Tab. 2).

Table 2 Emission factors (EF) and global warming potentials (GWP) of greenhouse gases.

\begin{tabular}{|c|c|c|}
\hline $\mathrm{EF}_{\text {diesel fuel }}$ & $2,7 \mathrm{~kg} \mathrm{CO} \mathrm{CO}_{2 \mathrm{eq}} / 1$ diesel & $\begin{array}{c}\text { Fruergaard et } \\
\text { al., } 2009\end{array}$ \\
\hline $\begin{array}{c}\mathrm{EF}_{\text {el cons }} \text { - Croatia grid } \\
\text { electricity } \\
\text { consumption }\end{array}$ & $0,212 \mathrm{~kg} \mathrm{CO} \mathrm{CO}_{2 \mathrm{q}} / \mathrm{MWh}$ & EIHP, 2013 \\
\hline $\begin{array}{c}\mathrm{EF} \mathrm{CH}_{4} \text { due to } \\
\text { leakages }\end{array}$ & $0.48 \mathrm{~kg} \mathrm{CH}_{4} / \mathrm{t}$ ww & IPPC, 2006 \\
\hline $\begin{array}{l}\text { EF }_{\text {el prod }} \text { - Croatia grid } \\
\text { electricity production }\end{array}$ & $0.327 \mathrm{~kg} \mathrm{CO} 2 \mathrm{eq} / \mathrm{MWh}$ & EIHP, 2013 \\
\hline $\mathrm{GWP} \mathrm{CH}_{4}$ & $21 \mathrm{~kg} \mathrm{CO} \mathrm{CO}_{2 \mathrm{e}} / \mathrm{kg} \mathrm{CH}_{4}$ & IPPC, 2006 \\
\hline
\end{tabular}

Grid electricity consumption for plant operation can be quantified as explained in the following formula:

Emel cons - Emissions from electrical consumption ( $\mathrm{kg}$ $\mathrm{CO}_{2 \mathrm{eq}}$ /tone of organic waste) $=\mathrm{EC} \times \mathrm{EFel}$ cons)

EC - Electricity consumption for operation activities (kWh/tonne of organic waste)

EFel cons - Emission factor of country grid electricity consumption $(\mathrm{kg} \mathrm{CO} 2 \mathrm{eq} / \mathrm{kWh})$

The fugitive loss of methane is difficult to establish by measurements and probably highly variable from facility to facility. IPCC gives ranges between 0 and $10 \%$ of the produced methane, but also states that 'Where technical standards for biogas plants ensure that unintentional $\mathrm{CH}_{4}$ emissions are flared, $\mathrm{CH}_{4}$ emissions are likely to be close to zero' [15]. In our calculations we used an average default value $\left(2 \mathrm{~kg}\right.$ of $\mathrm{CH}_{4} /$ tone of dry organic waste; IPCC, 2006) for methane emissions due to unavoidable leakages.

Em leakages - Emissions from leakages at biogas facility $(\mathrm{kg} \mathrm{CO} 2 \mathrm{eq} /$ tone of organic waste $)=\mathrm{ECH}_{4} \times \mathrm{GWPCH}_{4}$ $\mathrm{ECH}_{4}-$ Emissions of $\mathrm{CH}_{4}$ due to leakages $\left(\mathrm{kg}\right.$ of $\mathrm{ECH}_{4} /$ tone of organic waste)

$\mathrm{GWPCH}_{4}-$ Global warming potential of $\mathrm{CH}_{4}(21 \mathrm{~kg}$ $\mathrm{CO}_{2} / \mathrm{kg}$ of $\mathrm{CH}_{4}$ )
The energy from CHP was assumed to replace natural gas heat and Croatian grid mix electricity.

\section{Results}

The separate collection of OFMSW was introduced several years ago on the island of Krk. Such scheme allows considering the anaerobic digestion from different waste materials as sustainable waste management practice and should include energy, environmental and economic considerations. In this section we present the availability of different raw materials for $\mathrm{AD}$ and the potential for production of biogas on the island of Krk. The total annual amount of organic waste suitable for anaerobic digestion is $3075 \mathrm{t}$. It is observable that $3 / 4$ of the available raw material is represented by the OFMSW.

As Krk is an important summer tourist destination the availability of waste material has very pronounced seasonality (Tab. 3). The maximum availability of waste feedstock is in August, with $388 \mathrm{t}$ and by contrast, in January that amount is less than half with availability of only 114 t (Tab. 3).

The basic condition for a stable biogas production is a continuous inflow of raw materials having somewhat homogenous composition, therefore such differences in availability have to be taken into account when planning the capacity of the biogas plant. As observable from table 3 , there is a great variability in composition and the quality of the raw material for biogas production during the year. For instance in September, October and November there is a large influx of pomace from the production of olive oil and wine.

It is observable as well that the largest substrate availability and mass flow are in the month of August while the maximum biogas potential is in September (Tab. 3). This is due to the fact that the substrate composition in September is the most favourable for biogas production. The sudden change in the composition of the used raw materials can be the cause of changes in the structure and composition of bacterial population producing biogas and therefore can adversely affect the whole process of biogas production.

Table 3 Mass flow of substrate on monthly basis and the potential for biogas and biomethane production

\begin{tabular}{|c|c|c|c|c|c|c|c|c|c|}
\hline Waste origin & $\begin{array}{l}\text { Biowaste } \\
(201008)\end{array}$ & $\begin{array}{c}\text { Green waste } \\
(200201)\end{array}$ & Pomace & Whey & $\begin{array}{c}\text { Poultry } \\
\text { (liquid manure) }\end{array}$ & $\begin{array}{l}\text { Olive } \\
\text { cake }\end{array}$ & Total Waste & $\begin{array}{c}\text { Biogas } \\
/ \mathrm{m}^{3}\end{array}$ & $\begin{array}{c}\text { Biomethane } \\
/ \mathrm{m}^{3}\end{array}$ \\
\hline January & 56 & 9 & & 0,75 & 33,3 & 15 & 114 & 14603 & 9133 \\
\hline February & 77 & 23 & & 0,75 & 33,3 & 0 & 134 & 13858 & 8645 \\
\hline March & 106 & 13 & & 0,75 & 33,3 & 0 & 153 & 16067 & 10033 \\
\hline April & 241 & 20 & & 0,75 & 33,3 & 0 & 295 & 31614 & 19660 \\
\hline May & 219 & 12 & & 0,75 & 33,3 & 0 & 265 & 28393 & 17677 \\
\hline June & 259 & 14 & & 0,75 & 33,3 & 0 & 307 & 32948 & 20498 \\
\hline July & 331 & 7 & & 0,75 & 33,3 & 0 & 372 & 40294 & 25064 \\
\hline August & 347 & 7 & & 0,75 & 33,3 & 0 & 388 & 42121 & 26196 \\
\hline September & 250 & 19 & 85 & 0,75 & 33,3 & 0 & 388 & 55272 & 35702 \\
\hline October & 194 & 8 & & 0,75 & 33,3 & 65 & 301 & 44255 & 27518 \\
\hline November & 145 & 9 & & 0,75 & 33,3 & 21 & 209 & 26224 & 16337 \\
\hline December & 108 & 4 & & 0,75 & 33,3 & 3 & 149 & 16257 & 10167 \\
\hline TOTAL & 2333 & 145 & 85 & 9 & 400 & 104 & 3076 & 361906 & 226629 \\
\hline
\end{tabular}

Depending on the origin and the composition of the substrate there is a need for sorting and separation of unwanted and potentially harmful substances. As the main component is OFMSW, mainly composed of food waste from households and the tourism, there is a possibility that it contains parts of plastic, metal, wood or glass packaging that is not biodegradable and can also damage 
pumps and stirrers. Great care has to be taken to separate these components before they enter the biogas reactor.

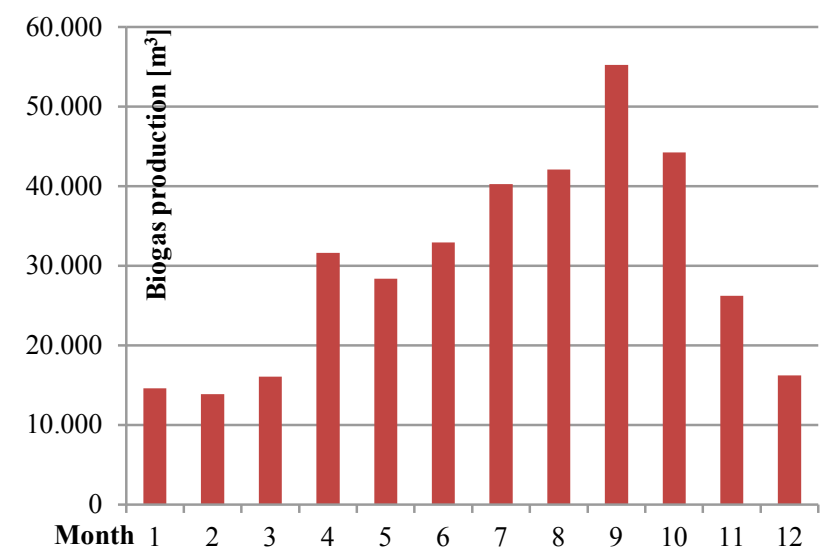

Figure 4 Monthly biogas production potential

\section{Technical aspects of the cogeneration plant 4.1 Potential for energy production}

It is evident that biogas produced from OFMSW and other types of biodegradable waste has considerable energy potential. The most efficient and technically viable way to produce energy from such energy source is a cogeneration process.

An alternative could be the production of biomethane that can be utilized in the main natural gas grid. The biogas has to be purified and treated so that it can be pumped and used in the natural gas grid. Given the seasonal variations of biogas production this option is appealing from a technical point of view. However biogas purification and conversion to biomethane is a costly process requiring equipment that is not suitable for small plants that use BMW. Besides, natural gas pipelines still do not exist in the island of Krk, and the timetable for construction of LNG terminal on the island is still not quite clear.

Table 4 Simulation of biomethane production and energy potential

\begin{tabular}{|l|c|c|c|c|}
\hline Month & $\begin{array}{c}\text { Hours } \\
\text { run } \\
\text { time }\end{array}$ & $\begin{array}{c}\text { Monthly } \\
\text { biomethane } \\
\text { production } \\
/ \mathrm{m}^{3} / \text { month }\end{array}$ & $\begin{array}{c}\text { Daily } \\
\text { biomethane } \\
\text { production } \\
/ \mathrm{m}^{3} / \text { day }\end{array}$ & $\begin{array}{c}\text { Biogas } \\
\text { energy } \\
\text { potential / } \\
\mathrm{kW} \cdot \mathrm{h} / \mathrm{month}\end{array}$ \\
\hline January & 679,5 & 9133,3 & 294,6 & 91332,6 \\
\hline February & 613,7 & 8644,9 & 308,7 & 86448,7 \\
\hline March & 679,5 & 10033,3 & 323,7 & 100333,3 \\
\hline April & 657,5 & 19659,7 & 655,3 & 196597,1 \\
\hline May & 679,5 & 17676,7 & 570,2 & 176767,3 \\
\hline June & 657,5 & 20497,9 & 683,3 & 204978,9 \\
\hline July & 679,5 & 25063,9 & 808,5 & 250638,6 \\
\hline August & 679,5 & 26196,4 & 845,0 & 261963,8 \\
\hline September & 657,5 & 35702,1 & 1190,1 & 357021,1 \\
\hline October & 679,5 & 27517,5 & 887,7 & 275174,7 \\
\hline November & 657,5 & 16336,5 & 544,6 & 163365,5 \\
\hline December & 679,5 & 10166,5 & 328,0 & 101665,3 \\
\hline Total & 8000,0 & 226628,7 & 620,9 & 2266287,0 \\
\hline
\end{tabular}

To determine the optimal power of the cogeneration unit daily biogas production and its heating value, dependent on the composition of the biogas and the methane content, have to be taken into account.
To calculate the maximum necessary capacity of the cogeneration power plant the peak biomethane production should be considered. As observable in Tab. 3 maximum biomethane production is in the month of September when it is possible to produce $55272 \mathrm{~m}^{3}$ of biogas with a methane share of $35702 \mathrm{~m}^{3}$. The dynamics of monthly biomethane production depends on the substrate composition.

The following table shows the biogas production and average working hours of the plant on monthly basis, as well as daily biomethane production estimate.

With the assumed biogas lower heating value of 10 $\mathrm{kWh} / \mathrm{m}^{3}$, the available maximum heat potential, or heat input for the cogeneration units is $357020 \mathrm{~kW} \cdot \mathrm{h}$.

Table 5 Case 1 - simulation of biogas power plant electrical energy production and power output - single cogeneration unit

\begin{tabular}{|c|c|c|c|c|c|}
\hline 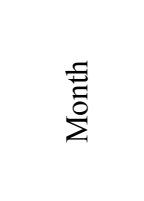 & 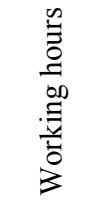 & 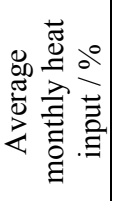 & 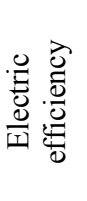 & 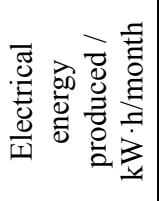 & 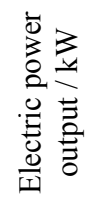 \\
\hline January & 679,5 & 25,08 & 0,28 & 25244,98 & 37,15 \\
\hline February & 613,7 & 26,28 & 0,28 & 24101,48 & 39,27 \\
\hline March & 679,5 & 27,55 & 0,28 & 28222,26 & 41,54 \\
\hline April & 657,5 & 55,78 & 0,33 & 64550,43 & 98,17 \\
\hline May & 679,5 & 48,54 & 0,32 & 56174,00 & 82,68 \\
\hline June & 657,5 & 58,16 & 0,33 & 67965,77 & 103,36 \\
\hline July & 679,5 & 68,82 & 0,34 & 86392,56 & 127,15 \\
\hline August & 679,5 & 71,93 & 0,35 & 91186,20 & 134,21 \\
\hline September & 657,5 & 100,0 & 0,37 & 132097,82 & 200,90 \\
\hline October & 679,5 & 75,56 & 0,35 & 96808,03 & 142,48 \\
\hline November & 657,5 & 46,35 & 0,31 & 51361,52 & 78,11 \\
\hline December & 679,5 & 27,92 & 0,28 & 28669,27 & 42,19 \\
\hline Total & 8000,0 & & & 752774,30 & \\
\hline Average & & 52,66 & 0,32 & & 93,93 \\
\hline
\end{tabular}

Analysing Tab. 4 for the maximum biogas production in September the cogeneration unit should have a heat load of $543 \mathrm{~kW}$ to operate continuously. In the same time January biogas production has the heat load for continuous operation drops of only $134,41 \mathrm{~kW}$. This means that the cogeneration unit should be operated intermittently as the biogas storage is emptied and slowly refilled again. This is also true if cogeneration units are operated at a reduced load, with reduced efficiency. Results of this mode of operation are interruptions in the energy production as well as frequent starting and stopping of the cogeneration units.

Since biogas production is a relatively slow process, the biogas plant should be operated in such a way that biogas production is met with the stable consumption from the cogeneration units thus to avoid interruptions in the operation of the cogeneration plant. To achieve this goal it is suggested that a concept of two cogeneration units be applied. The cogeneration units can operate close to maximum efficiency, with reduced emissions of harmful gases like nitrous oxides and carbon monoxide.

From the above stated we conclude that an optimization of the cogeneration power plant is necessary to make sure that it operates in an efficient manner.

For the first case a single cogeneration unit is applied with a $536 \mathrm{~kW}$ maximum heat input with the efficiency 
curve as in Fig. 2. The maximum electric power output is $199 \mathrm{~kW}$.

The cogeneration unit operates at lower loads most of the year and is only at its maximum heat input in the month of September.
In the second case the biogas power plant has two cogeneration units of $145 \mathrm{~kW}$ and $384 \mathrm{~kW}$ maximum heat input capacity, and $50 \mathrm{~kW}$ and $140 \mathrm{~kW}$ electric power maximum output.

Table 6 Case 2 - simulation of biogas power plant electrical energy production and power output - two cogeneration units

\begin{tabular}{|l|c|c|c|c|c|c|c|c|}
\hline \multirow{2}{*}{ Month } & \multirow{2}{*}{$\begin{array}{c}\text { Working } \\
\text { hours }\end{array}$} & $\begin{array}{c}\text { Cogenerator } 1-50 \mathrm{~kW} \\
\text { Average } \\
\text { monthly heat } \\
\text { input / \% }\end{array}$ & $\begin{array}{c}\text { Electric } \\
\text { efficiency / - }\end{array}$ & $\begin{array}{c}\text { Cogenerator 2-140 } \mathrm{kW} \\
\text { monthly } \\
\text { heat input / } \\
\%\end{array}$ & $\begin{array}{c}\text { Electric } \\
\text { efficiency / - }\end{array}$ & $\begin{array}{c}\text { Average } \\
\text { monthly } \\
\text { efficiency }\end{array}$ & $\begin{array}{c}\text { Electrical } \\
\text { energy } \\
\text { produced / } \\
\mathrm{kW} \cdot \mathrm{h} / \mathrm{mn} .\end{array}$ & $\begin{array}{c}\text { Electric } \\
\text { power } \\
\text { output } \\
/ \mathrm{kW}\end{array}$ \\
\hline January & 679,5 & 92,70 & 0,338 & & & 0,338 & 30947,5 & 45,5 \\
\hline February & 613,7 & 97,14 & 0,34 & & & 0,34 & 29623,3 & 48,3 \\
\hline March & 679,5 & 101,84 & 0,35 & & & 0,35 & 34760,6 & 51,2 \\
\hline April & 657,5 & & & 77,86 & 0,34 & 0,34 & 67564,2 & 102,8 \\
\hline May & 679,5 & & & 67,75 & 0,33 & 0,33 & 58588,7 & 86,2 \\
\hline June & 657,5 & & & 81,18 & 0,35 & 0,35 & 71249,0 & 108,4 \\
\hline July & 679,5 & & & 96,06 & 0,36 & 0,36 & 91392,5 & 134,5 \\
\hline August & 679,5 & & & 100,00 & 0,37 & 0,37 & 96664,6 & 142,3 \\
\hline September & 657,5 & 100 & 0,35 & 100,00 & 0,37 & 0,36 & 129392,2 & 196,8 \\
\hline October & 679,5 & & & 100,00 & 0,37 & 0,29 & 101539,5 & 149,4 \\
\hline November & 657,5 & & & 64,70 & 0,33 & 0,33 & 53531,4 & 81,4 \\
\hline December & 679,5 & 103,19 & 0,35 & & & 0,35 & 35327,9 & 52,0 \\
\hline Total & 8000 & & & & & & 800581,6 & \\
\hline Average & & 98,98 & 0,34 & 85,94 & 0,35 & 0,35 & & 99,98 \\
\hline
\end{tabular}

Comparing Tab. 5 and Tab. 6 it is evident that in Case 2 more electric energy and electric power is produced. Most of the year only one cogenerator is operational, and only in September both units are online.

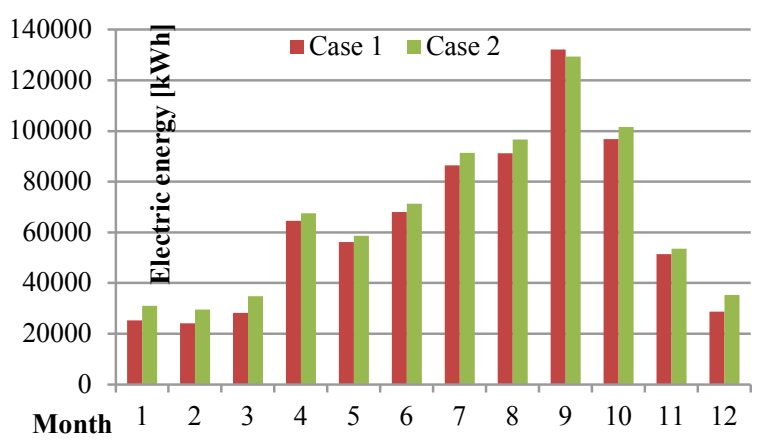

Figure 5 Electric energy production for Case 1 and Case 2

For some months Case 1 produces more electric energy and for others months Case 2 has better electric energy production, as evident from Fig. 3. When added together most yearly electric energy produced is in Case 2.

\subsection{Energy efficiency}

Since the dynamics of biogas production is highly variable throughout the year as seen from Table 4, most of the year biogas production is not sufficient for full load energy production of a single cogeneration unit in Case 1.

On the other hand, the biogas reactor needs constant heating in order to maintain the correct temperature for the methanisation process, thus the cogeneration units need to run constantly. In order to improve energy efficiency, authors have suggested the use of two cogeneration units (Case 2). With this approach the cogeneration units can be sized to the exact available capacity. We have shown that with the use of two cogeneration units the electric efficiency improves opposed to using one cogeneration unit. The overall energy efficiency also improves with this approach. With the same method an analysis of the heat energy production for both Case 1 and Case 2 has been performed with the following results shown in Tab. 7.

Table 7 Heat production of the biogas plant Case 1 and Case 2

\begin{tabular}{|l|c|c|}
\hline Case 1 & & \\
\hline Total heat produced: & 1134413 & $\mathrm{~kW} \cdot \mathrm{h}$ \\
\hline Overall heat efficiency: & 0,50 & - \\
\hline Average heating power: & 141,6 & $\mathrm{~kW}$ \\
\hline Case 2 & & \\
\hline Total heat produced: & 1250129 & $\mathrm{~kW} \cdot \mathrm{h}$ \\
\hline Overall heat efficiency: & 0,55 & - \\
\hline Average heating power: & 156,0 & $\mathrm{~kW}$ \\
\hline
\end{tabular}

Comparing Case 1 and Case 2 it is observable that overall energy efficiency is higher when using two cogeneration units Case 2 allowing the production of more electric and heat energy from the same substrate available.

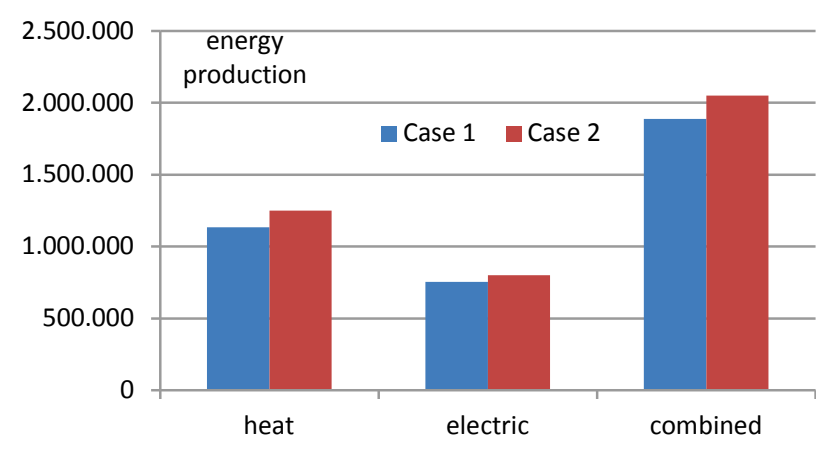

Figure 6 Heat, electric and combined efficiency for both cases 


\subsection{Sustainable heat use}

The process of mesophilic AD needs heat for maintaining of proper temperature in the reactor. This heat consumption is based on heat losses of the reactor itself, and that heat demand is related to ambient temperatures. In the case of steady substrate inflow winter heat demand is greater than for summer months. In the present biogas plant winter substrate inflow is greatly reduced therefore heat demand is reduced consequently.

Since the biogas plant that processes MSW is usually located near waste processing facilities there are limited possibilities of available thermal energy use.

The proposed solution is the use of heat for drying of the digestate by-product of the $\mathrm{AD}$ process. As the digestate has a high water content it is convenient to dry it before the transport and further usage or disposal at different sites.

\section{GHG reduction potential}

The disposal and treatment of organic waste can produce emissions of several greenhouse gases (GHG), released during the breakdown of organic matter in landfills. Additional emissions are produced during the transport and sorting processes. Energy recovery of organic waste minimizes the GHG emissions because the considered feedstock is renewable and displaces the share of energy otherwise produced by fossil fuels. For every megawatt of electricity generated through the digestion of organic waste, a megawatt of electricity from conventional, e.g., coal or oil-fired power plants is avoided, creating a net savings of emissions of greenhouse gases. Moreover, when an organic waste is delivered to a biogas facility, the methane that would have been generated if it had been sent to a landfill is avoided. Anaerobic digestion contributes to greenhouse gas (GHG) emissions, mainly from the use of fossil energy at the facility, emissions from the bioreactor and combustion of biogas, and emissions from the disposal/use of digestate. Equally important, AD also has a large potential for $\mathrm{GHG}$ emission savings, especially from substitution of fossil fuel by the biogas.

In order to quantify overall GHG emissions from anaerobic digestion, a calculation was made for quantification of both GHG emissions and $\mathrm{GHG}$ avoidance.

There are two major ways that anaerobic digestion could emit GHG: i) GHG emissions from fossil fuel (e.g. electricity and diesel) utilization for operation; and ii) GHG emissions from the reactor due to unavoidable leakages.

GWF of fuel combustion due to transport operations was calculated as $3,78 \mathrm{~kg} \mathrm{CO} 2 \mathrm{eq} /$ tone organic waste.

The emissions from leakages at biogas facility have been estimated as $10,08 \mathrm{~kg} \mathrm{CO}_{2 \mathrm{eq}} /$ tone of organic waste.

The produced electricity or the thermal energy from biogas could be used to replace fossil-fuel-based conventional electricity and thermal energy production and thereby reduce the GHG emissions from those conventional processes. Export of electricity to the grid results in GHG emission savings by avoiding emissions from substitution of electricity production with fossil fuels. We calculated that the biogas facility has a net release of electricity to the grid on a yearly basis of 227,6 $\mathrm{kW} \cdot \mathrm{h} /$ year. Considering the EFel prod $-0,327$ for the Croatian fuel mix in electricity production the avoided electricity production is $74,44 \mathrm{~kg} \quad \mathrm{CO}_{2 \mathrm{eq}} /$ tone organic waste.

We calculated $17,1 \mathrm{~kW} \cdot \mathrm{h} / \mathrm{t}$ of organic waste as electricity consumption which resulted in $3,6 \mathrm{~kg} \mathrm{CO} \mathrm{CO}_{2 \mathrm{eq}} / \mathrm{t}$ of organic waste GHG emissions.

The overall climate benefit or the impact from anaerobic digestion as an organic waste management option is calculated as follows: Net GHG emissions from anaerobic digestion $\left(\mathrm{kg} \mathrm{CO} \mathrm{CO}_{2 \mathrm{q}} /\right.$ tonne of organic waste $)=$ Total GHG emissions - Total GHG avoidance.

The result is a net saving of GHG emissions of 56,9 $\mathrm{kg} \mathrm{CO}$ 2eq $/$ tonne of organic waste.

\section{Conclusion}

This paper analyses the possibilities of biogas production from anaerobic digestion of organic waste in a Croatian island.

On the island of Krk the available feedstock quantities are relatively small. Particularly significant is the high variability of feedstock volumes depending on the period in the year. This is due to the fact that the island population greatly increases in the summer months and thus organic waste also increases. These variations in raw material composition are a challenge for planning and operating a biogas plant. Besides the seasonal variations in quantities, at certain periods of the year there is an influx of agriculture wastes that occur seasonally (autumn). Biogas production varies greatly between winter and summer months. The above poses great challenges for $\mathrm{AD}$ process and requires careful planning of the biogas production.

In order to analyse the most efficient process option with such disproportion of biogas availability the simulation of two cases - case 1 with one cogeneration unit, and case 2 with two cogeneration units was performed. The approach of two units, that operate based on the available biogas inflow, has shown to be more efficient than using a single unit. The second case shows more produced heat and electric energy and can be run constantly at near maximum efficiency. The overall energy efficiency improves, as shown in Fig. 6, by $8 \%$.

When using one cogeneration unit at lower loads in the winter months there is a risk of unstable operation with resulting interruptions in the energy production. This means that a back-up system should be installed for heating the biogas reactor, and other heat energy uses.

Heat that is produced in the cogeneration units could be efficiently used for digestate drying, thus reducing its mass and volume, resulting in lower costs of digestate transport and handling. However that option should be carefully examined as investment in a drying facility would be needed.

Net GHG emissions are negative which thus indicates the potential GHG savings from anaerobic digestion and the possibility to be a carbon sink. 


\section{References}

[1] Braun, R. Anaerobic digestion: a multi-faceted process for energy, environmental management and rural development. Improvement of crop plants for industrial end uses, Springer, Netherlands, 2007.

[2] Curry, N.; Pillay, P. Biogas prediction and design of a food waste to energy system for the urban environment. // Renewable Energy. 41, (2012), pp. 200-209. DOl: 10.1016/j.renene.2011.10.019

[3] FNR. Guide to biogas, Fachagentur nachwachsende Rohstoffe e. V., 2012.

[4] Zupančič, D.; Grilc, V. Anaerobic Treatment and Biogas Production from Organic Waste. // Management of Organic Waste, In Tech, 2012 URL: http://www.intechopen.com/ books/management-of-organic-waste/anaerobic-treatmentand-biogas-productionfrom-organic-wastes

[5] Krićka, T.; Voća, N.; Jurišić, V.; Matin, A. Unapređenje proizvodnje na poljoprivrednim gospodarstvima uvođenjem bioplinskih postrojenja. Studija // Ed. Grad Zagreb, Gradski ured za poljoprivredu i šumarstvo, 2007.

[6] Weiland, P. Biogas production: current state and perspectives. // Microbiology Biotechnology. 85, (2011), pp 849-860. DOI: 10.1007/s00253-009-2246-7

[7] Jeon, E. J.; Bae, S. J.; Lee, D. H.; Seo, D. C.; Chun, S. K.; Lee, N. H.; Kim, J. Y. Methane generation potential and biodegradability of MSW components. // Proceedings of Eleventh International Waste Management and Landfill Symposium / Sardinia, Italy, 2007.

[8] Owens, J. M.; Chynoweth, D. P. Biochemical methane potential of municipal solid waste components. // Wat. Sci. Technology. 27, (1993), pp. 1-14.

[9] Bogner, J.; Pipatti, R.; Hashimoto, S.; Diaz, C.; Mareckova, K.; Diaz, L. et al. Mitigation of global greenhouse gas emissions from waste. // Conclusions and strategies from the Intergovernmental Panel on Climate Change (IPCC) fourth assessment report, Waste Management and Research. 26, (2008), pp. 11-32.

[10] Fruergaard, T.; Astrup, T.; Møller, J.; Ekvall, T.; Christensen, T. H. Energy use and recovery in waste management and implications for accounting of greenhouse gases and global warming contributions. // Waste Management \& Research. 27, (2009), pp. 724-737. DOl: 10.1177/0734242X09345276

[11] Moller, J.; Boldrin, A.; Christensen, T. H. Anaerobic digestion and digestate use: accounting of greenhouse gases and global warming contribution. // Waste management \& research. 27, (2009), pp. 813-824. DOI: 10.1177/0734242X09344876

[12] Roth, U.; Döhler, H.; Hartmann, S.; Wulf, S. Treibhausgasbilanzen und $\mathrm{CO}_{2 \mathrm{eq}}$ Vermeidungskosten landwirtschaftlicher Biogasanlagen. // Biogas in der Landwirtschaft - Stand und Perspektiven / FNR/KTBLKongress, KTBL-Schrift 488 (2011), pp. 196-208.

[13] Voća, N.; Krička, T.; Jurišić, V.; Pavković, B.; Dragičević, V.; Delač, B.; Šegon, V.; Maras, H.; Jardas, D.; Čotar, A.; Ribić, B. Studija isplativosti korištenja biogenog otpadnog materijala $u$ postrojenju sanaerobnom fermentacijom na otoku Krku,University of Zagreb - Faculty of Agriculture, Regional energy agency of northwest Croatia, University of Rijeka - Faculty of Engineering and Regional energy agency REA "Kvarner", Zagreb, 2012.

[14] Gentil, E.; Aoustin, E.; Crawford, G.; Christensen, T. H. Greenhouse gas accounting and waste management. // Waste Management \& Research. 27, (2009), pp. 696-706. DOI: $10.1177 / 0734242 \times 09346702$

[15] IPCC, Guidelines for National Greenhouse Gas Inventories, Prepared by the National Greenhouse Gas Inventories Programme, Eggleston HS Buendia L Miwa K Ngara T Tanabe, K (Eds.), IGES, Japan, 2006.
[16] Menikpura, N.; Sang-Arun, J. GHG calculator for solid waste, 2013. URL: http://pub.iges.or.jp/modules/envirolib/ view.php?docid=4273 (09. 02. 2015)

[17] UNFCCC, Project and leakage emissions from anaerobic digesters. Methodological Tool, 2012, Annex 32, 11 p. URL:http://cdm.unfccc.int/methodologies/PAmethodologie s/tools/am-tool-14-v1.pdf. (09. 02. 2015)

\section{Authors' addresses}

Viktor Dragičević, PhD*

Faculty of engineering University of Rijeka

Vukovarska 58, 51000 Rijeka, Croatia

E-mail: viktor.dragicevic@riteh.hr

Marin Miletić, PhD*

Energetski institut Hrvoje Požar

Savska cesta 163, 10001 Zagreb, P.P. 141, Croatia

E-mail: mmiletic@eihp.hr

Branimir Pavković. PhD*

Faculty of engineering University of Rijeka

Vukovarska 58, 51000 Rijeka, Croatia

E-mail: branimir.pavkovic@riteh.hr

*The authors contributed equally to this work 